\title{
Cytotoxicity of Bovine and Porcine Collagen Membranes in Mononuclear Cells
}

\author{
Camilla Christian Gomes MOURA ${ }^{1}$ \\ Priscilla Barbosa Ferreira SOARES ${ }^{2}$ \\ Karine Fernandes CARNEIRO ${ }^{2}$ \\ Maria Aparecida de SOUZA $^{3}$ \\ Denildo MAGALHÃES ${ }^{2}$
}

\author{
${ }^{1}$ Department of Operative Dentistry and Dental Materials, Dental School, \\ UFU - Federal University of Uberlândia, Uberlândia, MG, Brazil \\ ${ }^{2}$ Department of Periodontology and Implantology, Dental School, \\ UFU - Federal University of Uberlândia, Uberlândia, MG, Brazil \\ ${ }^{3}$ Department of Immunology and Parasitology, UFU - Federal University of Uberlândia, Uberlândia, MG, Brazil
}

\begin{abstract}
This study compared the cytotoxicity and the release of nitric oxide induced by collagen membranes in human mononuclear cells. Peripheral blood was collected from each patient and the separation of mononuclear cells was performed by Ficoll. Then, $2 \times 10^{5}$ cells were plated in 48-well culture plates under the membranes in triplicate. The polystyrene surface was used as negative control. Cell viability was assessed by measuring mitochondrial activity (MTT) at 4, 12 and 24 h, with dosage levels of nitrite by the Griess method for the same periods. Data had non-normal distribution and were analyzed by the Kruskal-Wallis test ( $<<0.05)$. Statistically significant differences $(p<0.05)$ were observed between the membranes and the control in the experimental period, although there was a significant reduction in viability over time $(\mathrm{p}<0.01)$. At 4 and $12 \mathrm{~h}$, the porcine membrane induced a higher release of nitrite compared with the control and bovine membrane, respectively $(\mathrm{p}<0.01)$, and this difference was maintained at $24 \mathrm{~h}(\mathrm{p}<0.05)$. This in vitro study showed that the porcine collagen membrane induces an increased production of proinflammatory mediators by mononuclear cells in the first hours of contact, decreasing with time.
\end{abstract}

Key Words: cell cytotoxicity, collagen membranes, nitric oxide.

\section{INTRODUCTION}

Guided tissue regeneration (GTR) is a procedure used to control early periodontal surgical wound healing dynamics in order to promote periodontal regeneration $(1,2)$. In addition, it has been applied to bone and periimplant defects, and to bone augmentation procedures prior to implant placement $(3,4)$. The principle of GTR is to use a membrane as a mechanical barrier to protect the blood clot, create space and facilitate the repopulation of the defect with cells with regenerative potential $(5,6)$.

Several materials have been used as barriers, namely polytetrafluoroethylene (PTFE), collagen, polyglycolic acid and copolymers $(3,7)$, which are classified as non-absorbable or bioabsorbable $(3,4)$. The use of non-absorbable membrane has been limited by the need of second surgery for membrane removal and its high membrane exposure rate (8), increased cost, risk of postsurgical infection, and possible suboptimal bone regeneration (9).

Consequently, a number of bioabsorbable barrier materials have been clinically used in GTR procedures $(5,6,10)$. These barriers are currently produced by collagen reconstitution using cross-linking techniques (4) to reduce the fast resorption and the lack of stability in the surgical area. However, the techniques used to multiply the links between collagen molecules, increasing the stiffness and slowing down the resorption of the collagen barrier, may increase its cytotoxicity (7). The properties of collagen barriers may also be affected by the origin of the collagen used in their fabrication $(7,11)$.

Correspondence: Prof. Dr. Denildo de Magalhães, Faculdade de Odontologia, Universidade Federal de Uberlândia, Área de Periodontia e Implantodontia, Avenida Pará, 1720, Campus Umuarama, Bloco 2G, 38405-902 Uberlândia, MG, Brasil. Tel: 55-34-3218-2431. e-mail: denildo@ foufu.ufu.br 
Bovine collagen membranes are largely produced by biomaterial industry, though collagen of porcine origin has been shown to be a promising alternative in GTR $(1,5,12)$. However, few studies have analyzed the inflammatory potential of collagen membranes $(6,13)$.

Considering that biocompatibility is a mandatory prerequisite for its human therapeutic use, GTR barriers must be evaluated regarding their inflammatory and immunogenic properties $(6,11)$. The aim of the present study was to assess the short-term cytotoxicity and the release of NO, a proinflammatory molecule, using human mononuclear cell culture as model.

\section{MATERIAL AND METHODS}

In this study, the tests were done in monocyte human primary cell culture plated in bovine and porcine collagen membranes, to evaluate the cytotoxicity and amount of nitrite released along the time. The research project was approved by the Ethics Committee of the Federal University of Uberlândia, MG, Brazil, and written informed consent was obtained from all blood donors.

\section{Human Peripheral Blood Monocyte/Macrophage Culture}

Whole blood $(40 \mathrm{~mL})$ was drawn into heparinized tubes from healthy volunteers and diluted at 2:1 in Hank's Balanced Salt Solution (HBSS). The diluted blood (7 mL) was carefully placed on top of $3 \mathrm{~mL}$ of polyvinylpyrrolidone coated silica gel (Percoll; GE Healthcare, Chalfont, Bucks, UK) in conical centrifugation tubes and were centrifuged at room temperature at $1000 \times \mathrm{g}$ for $30 \mathrm{~min}$ to separate monocytes and lymphocytes from remaining blood elements. The interface, containing mononuclear cells was aspirated and transferred to another tube containing cold HBSS and centrifuged at $1000 \times \mathrm{g}$ for $10 \mathrm{~min}$. After, the supernatant was discarded and the cells were resuspended in Roswell Park Memorial Institute (RPMI) 1640 supplemented with l-glutamine (2 mM) (Gibco, Grand Island, NY, USA), heat-inactivated fetal calf serum (FCS) (5\%) (Corning Costar, Brumath, France), penicillin (100 IU/ $\mathrm{mL})$ and streptomycin $(100 \mathrm{mg} / \mathrm{mL})$. Following, the cell concentration was counted and adjusted to $2 \times 10^{5} \mathrm{~mL}$ cell was added to bovine or porcine collagen membranes into 48 well culture plates. After $4 \mathrm{~h}$, the plate was centrifuged at $200 \times \mathrm{g}$, the supernatant was collected and the medium was changed by RPMI 1640 containing $10 \%$ FCS. The polystyrene surface (PS) was used as control. The cells were cultivated for 4,12 and $24 \mathrm{~h}$; in each time point, the medium was aspirated and renewed. The culture was done in triplicate for each membrane in each time point (4, 12 and $24 \mathrm{~h})$.

\section{Cell Cytotoxicity}

After 4, 12 and $24 \mathrm{~h}$, the medium was removed and $200 \mu \mathrm{L}$ of fresh medium and $20 \mathrm{Ll}$ of 3-[4,5-dimethylthiazol-2-yl]-2,5-diphenyl tetrazolium bromide (MTT) solution (Sigma-Aldrich Corp., St. Louis, MO, USA) was added to each well in order to measure mitochondrial activity of the cells. Absorbance was measured after $4 \mathrm{~h}$ of contact with MTT salt at 570 $\mathrm{nm}$ using a plate reader. The results were expressed as the average absorbance values of three replicates.

\section{Measurement of Nitric Oxide (NO)}

The production of NO was determined by measuring the accumulated level of nitrite in the culture supernatant using a colorimetric reaction with Griess reagent ( $0.1 \% \mathrm{~N}-(1$-naphthyl) ethylenediamine dihydrochloride, $1 \%$ sulfanilamide and $2.5 \% \mathrm{H}_{3} \mathrm{PO}_{4}$ ). Equal volumes of culture supernatant and Griess reagent were mixed and incubated in the dark for $10 \mathrm{~min}$ at room temperature and absorbance at $540 \mathrm{~nm}$ was measured with a microplate reader. The concentration of nitrite in the samples was determined from a sodium nitrite standard curve (200-1.6 mM). This procedure was done in triplicate for all samples, in each time point $(4,12$ and $24 \mathrm{~h}$ ).

\section{Statistical Analysis}

The Shapiro-Wilk test was used to test the normality of distribution. As data were not normally distributed, the Kruskal-Wallis test was performed for comparisons among the groups (bovine collagen membrane, porcine collagen membrane and control PS). P values less than 0.05 were considered statically significant.

\section{RESULTS}

There was statistically significant difference in cell viability among the bovine, porcine and PS (control) 
groups in all time points $(4 \mathrm{~h}, \mathrm{p}=0.0231 ; 12 \mathrm{~h}, \mathrm{p}=0.01803$; $24 \mathrm{~h}, \mathrm{p}=0.0097$ ) (Fig . 1A-C, respectively). At $4 \mathrm{~h}$, the highest viability values were observed in the bovine group (Fig. 1A). At 12 and $24 \mathrm{~h}$, the porcine group presented the lowest viability values compared with the PS (control) group (Fig. 1B and 1C, respectively). The mean absorbance values related to cell viability demonstrated a decrease on cell viability along the time (Fig. 2) for both membranes (bovine, $\mathrm{p} \leq 0.001$; porcine, $\mathrm{p} \leq 0.01$ ) (Fig. $2 \mathrm{~B}$ and $2 \mathrm{C}$ ) and for the PS (control) group $(\mathrm{p} \leq 0.01$, Fig. 2A).

At 4 and $12 \mathrm{~h}$ of cell culture, the nitrite levels produced by mononuclear cells cultivated in porcine
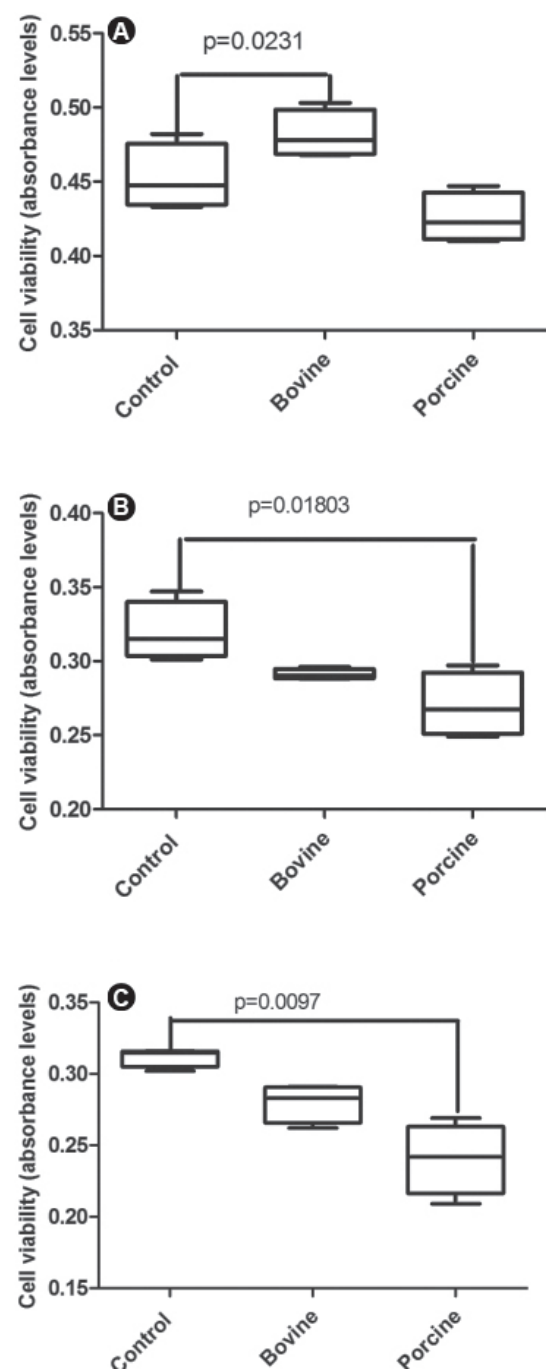

Figure 1. Boxplot demonstrating absorbance levels of monnuclear cell culture at the three time points of the study : $4 \mathrm{~h}$ (A), $12 \mathrm{~h}$ (B) and $24 \mathrm{~h}(\mathrm{C}) . \mathrm{p}<0.05$ indicate statistically significant difference. membrane were significantly higher than in the PS (control) group or in the bovine membrane, respectively (4 h p=0.0070; $12 \mathrm{~h} \mathrm{p}=0.007$ ) (Fig. $3 \mathrm{~A}$ and 3B, respectively). At $24 \mathrm{~h}$, higher nitrite levels detected in the supernatant of porcine membrane were maintained compared with the other groups ( $p=0.0072)$ (Fig. $2 \mathrm{C}$ ). The amount of nitrite released by cells cultured on PS did not show differences along the time $(p=0.2679)$ (Fig.
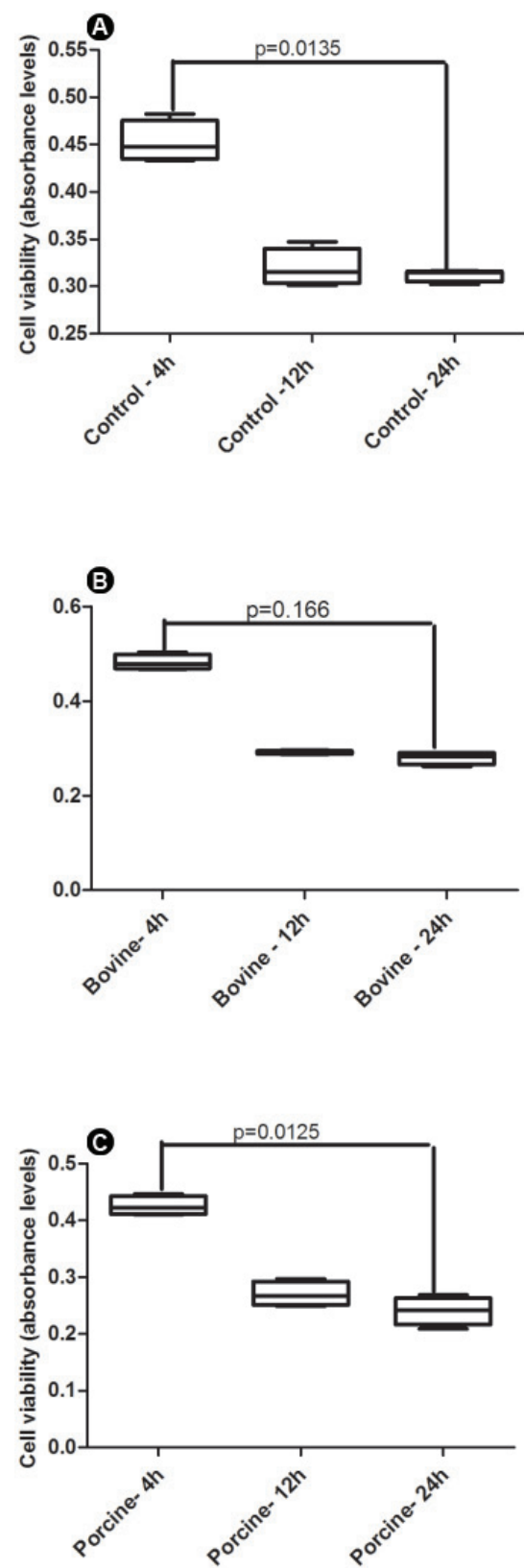

Figure 2. Boxplot demonstrating absorbance levels of monnuclear cell culture along the time (4, 12 and $24 \mathrm{~h}) . \mathrm{A}=$ Control group; B $=$ Bovine collagen membrane; $\mathrm{C}=$ Porcine collagen membrane. $\mathrm{p}<0.05$ indicate statistically significant difference. 
4A). The kinetics of nitrite release demonstrated that the bovine membrane induced the highest production of this mediator at $24 \mathrm{~h}$ compared with $12 \mathrm{~h}(\mathrm{p}=0.0070)$ (Fig. 4B). Conversely, the cells cultured on bovine membrane released high amounts of nitrite at $4 \mathrm{~h}$ showing significant reduction at $12 \mathrm{~h}(\mathrm{p}=0.0069)$ (Fig. $4 \mathrm{C})$. Figure 4 shows the data for the NO levels, comparing the values along the time for each group.
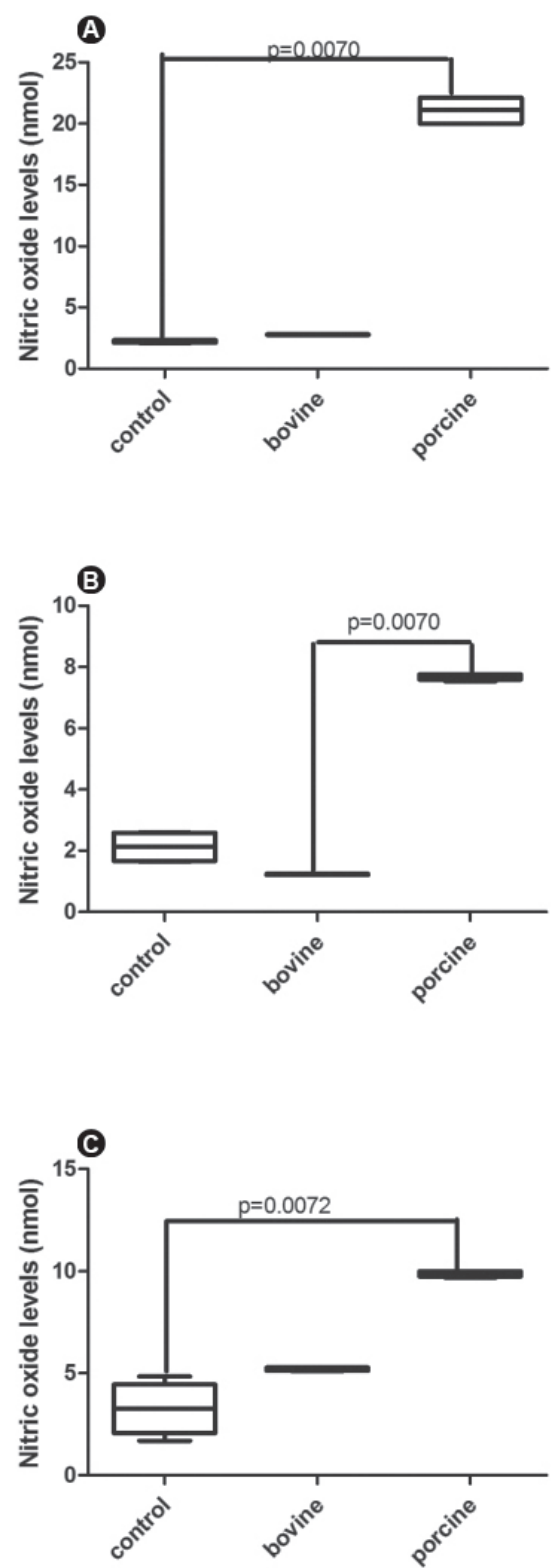

Figure 3. Boxplot demonstrating nitric oxide levels released by nonnuclear cells at the three time points of the study: $4 \mathrm{~h}$ (A), $12 \mathrm{~h}(\mathrm{~B})$ and $24 \mathrm{~h}(\mathrm{C})$ in culture. $\mathrm{p}<0.05$ indicate statistically significant difference.

\section{DISCUSSION}

Collagen barriers used as membranes in GTR are mechanically malleable, adaptable and easy to handle, which is beneficial for clinical applications $(4,6)$. Frequently, the collagen used to fabricate the membranes is of bovine and porcine origin. According
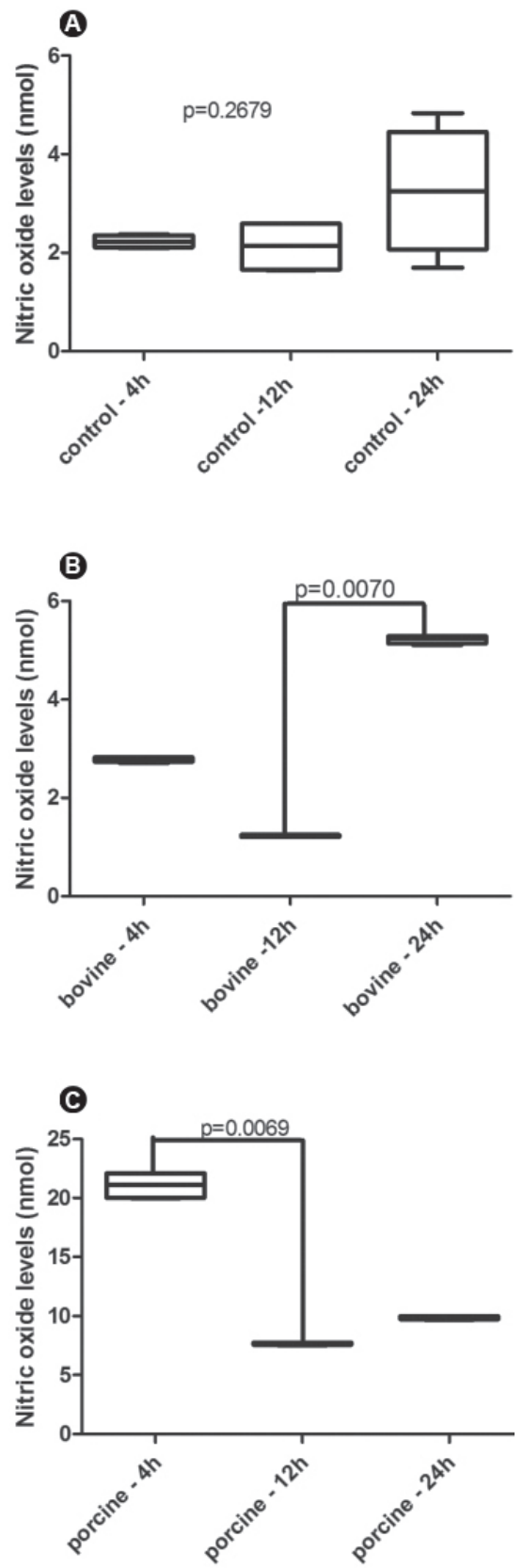

Figure 4. Boxplot demonstrating nitric oxide levels released by nonnuclear cell culture along the time $(4,12$ and $24 \mathrm{~h}) . \mathrm{A}=\mathrm{Contro}$ group; $\mathrm{B}=$ Bovine collagen membrane; $\mathrm{C}=$ Porcine collagen membrane. $p<0.05$ indicate statistically significant difference. 
to Schlegel et al. (14) and Camargo et al. (1), porcine collagen membranes appear to be well tolerated, without immunogenic response. In a literature review, Behring et al. (7) point out the influence of collagen origin in membrane properties. Although there is no agreement regarding the influence of collagen origin and the biological properties of GTR membranes, some studies have demonstrated differences in the cytotoxicity (11) and cell adhesion (5) promoted by bovine and porcine collagen membranes. The lack of consensus regarding the collagen origin and cell behavior stimulated the development of this research.

In the present study, influence of membrane origin on cell viability was observed. Both collagen membranes were produced according to the same method, varying only the source of collagen. The results showed that porcine collagen membranes were slightly more toxic than PS (control group), promoting cell death, as demonstrated by the MTT assay in 12 and $24 \mathrm{~h}$. However, the decrease in the absorbance levels observed along the time reflects the absence of proliferative capability of monocytes without lipopolysaccharide stimulus. According to Mebouta-Nkamgueu et al. (15), the use of primary cell culture is a useful tool in biomaterial research. Immortalized cells did not demonstrate the same pattern of response than monocyte/macrophage cells for in vitro biomaterial tolerance evaluation $(15,16)$.

Previous studies have demonstrated a cell proliferative ability of collagen barriers $(7,9)$; however, those studies used immortalized cell culture and a range of bioabsorbable and non-absorbable membranes such as Bioguide (12). In general, in vitro studies involving membranes or barriers used in GTR are done with fibroblasts or osteoblasts $(5,9,12)$. The present study used human mononuclear cells as a biological model aiming at mimicking the biological environment. Monocytes/ macrophages are responsible for the production of the complex of enzymes that degrade the collagen barriers (2). Furthermore, they are among the first cells to enhance the surgical site and are essential to determine the inflammation course. Monocytes/macrophages release a range of biological mediators such as cytokines, reactive oxygen species, nitrogen metabolites (6) and hydrolytic enzymes (2).

In the present study, NO was evaluated as an intermediate reactive of nitrogen produced by macrophages, which is involved in the wound healing process (17). The effects of this metabolite are especially relevant to the inflammatory phase of wound healing.
NO regulates the cellular mechanisms of repair, influencing cytokine production and the transition from the inflammatory phase to the regenerative phase (18). According to Schwentker et al. (17), basal levels of NO are important in the control of homeostasis, while an increase in the levels of this free radical contributes to tissue destruction.

In this study, the control group (PS) represented the basal levels of NO production, serving as a comparison with bovine and porcine membranes. Within $4 \mathrm{~h}$, the highest production of NO was induced by porcine membrane, decreasing at $12 \mathrm{~h}$, but remaining higher than in the control or bovine group. Although data obtained from an experimental model in vitro cannot be extrapolated to in vivo conditions and considering the limitations of this study, it is possible to speculate that the collagen membrane activates a proinflammatory profile in the first hour after plating, reducing the cytotoxicity with time. Zheng et al. (11) found residues of DNA in a porcine collagen membrane, which are probably related to the increased inflammatory reaction in mice and rats observed by the authors. In the present study, the manufacturer did provide the details regarding the production method, and so the same conclusion could not be drawn. However, correlating the data of the present study with cross-linking techniques commonly used for stiffening and slowing down the barrier degradation (7), it is possible to speculate that the method used to produce the porcine membranes induced a greater release of $\mathrm{NO}$ by macrophages.

It may concluded that the two membranes are acceptable, although the porcine collagen membrane induced a greater activation of mononuclear cells during the first $12 \mathrm{~h}$ of culture, resulting in a greater $\mathrm{NO}$ release in this period. Additionally, the porcine collagen membrane showed lower viability values compared with the control group. Further in vitro studies should be conducted using coculture models for elucidating the interaction of membranes with other immune cells such as neutrophils and fibroblasts.

\section{RESUMO}

Neste estudo foi comparada a citoxicidade e a liberação de nitrito induzidos por membranas de colágeno bovino e suíno em células mononucleares humanas. Foram coletados sangue periférico de cada paciente, e realizada separação de mononucleares por gradiente de Ficoll. Um total de $2 \times 10^{5}$ células foram plaqueadas em placas de cultura de 48 poços sob as membranas, em triplicata. $\mathrm{O}$ poço sem membrana serviu como controle negativo. A viabilidade celular foi avaliada medindo a atividade mitocondrial (MTT) 
em 4,12 e 24 h, com dosagens dos níveis de nitrito pelo método de Griess nos mesmos períodos. As amostras não apresentaram distribuição normal, sendo realizado o teste de Kruskal-Wallis $(\mathrm{p}<0,05)$. Foram observadas diferenças estatisticamente significantes entre as membranas e o controle nos período analisados $(\mathrm{p}<0,05)$, embora tenha ocorrido redução da viabilidade em função do tempo $(\mathrm{p}<0,01)$. Em 4 e $12 \mathrm{~h}$ a membrana suína induziu maior liberação de nitrito comparado ao controle e à membrana bovina, respectivamente $(\mathrm{p}<0,01)$. Tal diferença foi mantida em $24 \mathrm{~h}(\mathrm{p}<0,05)$. Este estudo in vitro demonstrou que a membrana colágena suína induz uma maior produção de mediador pró-inflamatório pelas células mononucleares nas primeiras horas de contato, diminuindo com o tempo.

\section{REFERENCES}

1. Camargo PM, Lekovic V, Weinlaender M, Nedic M, Vasilic $\mathrm{N}$, Wolinsky LE, et al.. A controlled re-entry study on the effectiveness of bovine porous bone mineral used in combination with a collagen membrane of porcine origin in the treatment of intrabony defects in humans. J Clin Periodontol 2000;27:889-896.

2. Bornstein MM, Heynen G, Bosshardt DD, Buser D. Effect of two bioabsorbable barrier membranes on bone regeneration of standardized defects in calvarial bone: a comparative histomorphometric study in pigs. J Periodontol 2009;80:12891299.

3. Parrish LC, Miyamoto T, Fong N, Mattson JS, Cerutis DR. Non-bioabsorbable vs. bioabsorbable membrane: assessment of their clinical efficacy in guided tissue regeneration technique. A systematic review. J Oral Sci 2009;51:383-400.

4. Lee CK, Koo KT, Kim TI, Seol YJ, Lee YM, Rhyu IC, et al. Biological effects of a porcine-derived collagen membrane on intrabony defects. J Periodontal Implant Sci 2010;40:232-238.

5. Takata T, Wang HL, Miyauchi M. Migration of osteoblastic cells on various guided bone regeneration membranes. Clin Oral Implants Res 2001;12:332-338.

6. Patino MG, Neiders ME, Andreana S, Noble B, Cohen RE. Cellular inflammatory response to porcine collagen membranes. J Periodontal Res 2003;38:458-464.

7. Behring J, Junker R, Walboomers XF, Chessnut B, Jansen JA. Toward guided tissue and bone regeneration: morphology, attachment, proliferation, and migration of cells cultured on collagen barrier membranes. A systematic review. Odontology 2008;96:1-11.
8. Sculean A, Chiantella GC, Windisch P, Arweiler NB, Brecx M, Gera I. Healing of intra-bony defects following treatment with a composite bovine-derived xenograft (Bio-Oss Collagen) in combination with a collagen membrane (Bio-Gide PERIO). J Clin Periodontol 2005;32:720-724.

9. Kasaj A, Reichert C, Götz H, Röhrig B, Smeets R, Willershausen B. In vitro evaluation of various bioabsorbable and nonresorbable barrier membranes for guided tissue regeneration. Head Face Med 2008:14:4-22.

10. Patino MG, Neiders ME, Andreana S, Noble B, Cohen RE. Collagen as an implantable material in medicine and dentistry. $\mathrm{J}$ Oral Implantol 2002;28:220-225.

11. Zheng MH, Chen J, Kirilak Y, Willers C, Xu J, Wood D. Porcine small intestine submucosa (SIS) is not an acellular collagenous matrix and contains porcine DNA: possible implications in human implantation. J Biomed Mater Res B Appl Biomater 2005;73:6167.

12. Rothamel D, Schwarz F, Sculean A, Herten M, Scherbaum W, Becker J. Biocompatibility of various collagen membranes in cultures of human PDL fibroblasts and human osteoblast-like cells. Clin Oral Implants Res 2004;15:443-449.

13. Wan LS, Xu ZK, Huang XJ, Huang XD, Yao K. Cytocompatibility of poly (acrylonitrile-co-N-vinyl-2-pyrrolidone) membranes with human endothelial cells and macrophages. Acta Biomater 2007;3:183-190.

14. Schlegel AK, Möhler H, Busch F, Mehl A. Preclinical and clinical studies of a collagen membrane (Bio-Gide). Biomaterials 1997; 18:535-538.

15. Mebouta-Nkamgueu E, Adnet JJ, Ittelet D, Laurent-Maquin D, Bouthors S, Potron G, et al.. Human monocyte-derived macrophages and dendritic cells as targets for biomaterial cytocompatibility studies using an improved in vitro culture system. J Mater Sci Mater Med 2001;12:351-357.

16. Chamberlain LM, Godek ML, Gonzalez-Juarrero M, Grainger DW. Phenotypic non-equivalence of murine (monocyte-) macrophage cells in biomaterial and inflammatory models. J Biomed Mater Res A 2009;88:858-871.

17. Schwentker A, Vodovotz Y, Weller R, Billiar TR. Nitric oxide and wound repair: role of cytokines? Nitric Oxide 2002;7:1-10

18. Williams D. The role of nitric oxide in biocompatibility. Med Device Technol 2008;19:8-10 